\title{
COMPARATIVE ANALYSIS OF THE EDUCATIONAL SYSTEMS IN POLAND AND THE UNITED STATES
}

\author{
Zygmunt Karol ŁUKASZCZYK ${ }^{1 *}$, Michalene Eva GREBSKI ${ }^{2}$ \\ ${ }^{1}$ Wydział Organizacji i Zarządzania/CKU, Politechnika Śląska, Poland; zygmunt.lukaszczyk@polsl.pl, \\ ORCID: 0000-0003-2370-1507 \\ ${ }^{2}$ Northampton Community College, Tannersville, PA 18466, USA; megrebski@northampton.edu, \\ ORCID: 0000-0002-3487-4473 \\ * Correspondence author
}

Purpose: The goals of the paper was a comparative analysis of educational systems as well as educational standards and funding in Poland and the United States. This was done for the purpose of identifying the best practices in both systems.

Design/methodology approach: Two educational systems, Hazleton (PA-USA) and Rybnik (Poland) were analyzed from the perspective of the structure of education, educational standards and funding. The sources of information included, but not limited to the Polish Ministry of Education, Hazleton Area School District, Pennsylvania Department of Education and the United States Department of Education.

Findings: The educational systems in Poland and the United States have more similarities than differences. The subjects being taught as well as the educational standards are similar. The educational system is more uniform throughout Poland because it is centrally administered by the Ministry of Education. The Performance scores of students are slightly higher in Poland. This is true in Mathematics, Reading and Science. The educational system in the United States is neither uniform throughout the country nor throughout the state of Pennsylvania. It may also vary from one school district to another school district.

Research Limitations: The research limitation was the comparison of one school district Hazleton, PA (USA) with the school district in Rybnik (Poland). No competency testing was done by the authors in either of the school districts. Student competency comparison was done by using the standardized testing data obtained from the Ministry of Education (Poland) and the Department of Education (Pennsylvania).

Practical Implications: A comparative analysis of the educational systems in Poland and the United States may allow for identifying the best and most effective practices which could be implemented in both countries.

Social Implications: The educational system in the United States allows for dual enrollment (high school and university at the same time). Piloting a similar model in Poland would have significant social implications.

Originality/value: Identifying the best and most effective educational practices in Poland and the United States is critical for planning improvements and developing a best practices model.

Keywords: Comparative Study of Educational Systems, Polish Education, United States Education, Educational Standards, Educational Funding.

Category of the paper: Case study. 


\section{Introduction}

The authors of this paper have researched the most current data related to the educational systems in Poland and the United States. The subtopics of this paper are the history, educational standards and funding related to the educational systems in these two countries. Most of the data comes from government sources. The comparison of the historical development, standards and funding uses data compiled mostly from government sources.

\section{Educational System in Poland}

Historically, the education of Polish society dates to the early $12^{\text {th }}$ century. The library catalogue of the Cathedral Chapter of Kraków (1110 AD) shows that Polish intellectuals had access to European literature. Jagiellonian University (the first university of Poland and second oldest university in Central Europe) was established in 1364 . In the $16^{\text {th }}$ century, $90 \%$ of all parishes in Poland had basic level schools. Although the idea of compulsory education was proposed at the time, it was not formally introduced until the early $19^{\text {th }}$ century.

The Polish system of education is undergoing significant changes, which will be implemented gradually according to the timeline shown in Table 1. The old system contained six years of elementary school followed by three years of middle school. After middle school, the student can enter an academic high school (three years), technical high school (four years) or a technical vocational school (three years).

The proposed educational structure is to include:

- 8-year elementary school,

- 4-year academic high school,

- 5-year technical high school,

- 3-year first-degree vocational technical school,

- 2-year second-degree vocational technical school,

- 3-year vocational school,

- 2.5-year post-secondary school.

Table 1.

Detailed timeline of the scope of changes in the Polish educational system

\begin{tabular}{|l|l|}
\hline Deadline & Scope of Change \\
\hline \multirow{3}{*}{1 September 2017 } & $\begin{array}{l}\text { - To implement the new curriculum for Grades I, IV and VII. } \\
\text { - To begin the implementation of the 8-year elementary school and the 3-year first- } \\
\text { degree vocational technical school. }\end{array}$ \\
& $\begin{array}{l}\text { - To discontinue recruitment of students to middle school. } \\
\text { - To implement a new curriculum in the 4-year technical high school and vocational } \\
\end{array}$ \\
& schools.
\end{tabular}


Cont. table 1.

\begin{tabular}{|c|c|}
\hline 1 September 2018 & $\begin{array}{l}\text { - To implement a new curriculum in Grades II, V and VIII of elementary school. } \\
\text { - There will be no classes of Grade I and Grade II in middle school due to the gradual } \\
\text { elimination of that school. }\end{array}$ \\
\hline April 2019 & $\begin{array}{l}\text { - To administer, for the last time, the final exams at the end of middle school. } \\
\text { - To administer the first-time final exams at the end of Grade VIII in elementary } \\
\text { school. The exam tests three subjects: Polish language, foreign language and } \\
\text { mathematics. }\end{array}$ \\
\hline 1 September 2019 & $\begin{array}{l}\text { - To implement a new programme in Grade I of the 4-year academic high school and } \\
\text { 5-year technical high school, as well as the first-degree technical vocational school } \\
\text { (for the first graduates of the 8-year elementary school). } \\
\text { - To begin work on a 4-year academic high school and 5-year technical high school } \\
\text { (in which students will be admitted after Grade VIII of elementary school). } \\
\text { - At the same time, the graduates of middle school will continue in a 3-year academic } \\
\text { high school or a 4-year technical high school. } \\
\text { - To discontinue and close middle schools. }\end{array}$ \\
\hline 1 September 2020 & $\begin{array}{l}\text { - To create a 2-year second-degree vocational technical school. } \\
\text { - To implement a new curriculum in Grade I of the 2-year second-degree vocational } \\
\text { technical school. }\end{array}$ \\
\hline 1 September 2021 & $\begin{array}{l}\text { - To implement a new curriculum in Grade II of the 2-year second-degree vocational } \\
\text { technical school. }\end{array}$ \\
\hline May 2022 & $\begin{array}{l}\text { - To administer, for the last time, national testing in the 3-year academic high school } \\
\text { according to the "old rules". } \\
\text { - To administer an exam at the end of the eighth year for the first time in the new } \\
\text { formula from four subjects: Polish, Foreign Language, Mathematics and one item of } \\
\text { choice (from Biology, Chemistry, Physics, Geography and History). }\end{array}$ \\
\hline May 2023 & $\begin{array}{l}\text { To administer national testing in: } \\
\text { - 4-year academic high school. } \\
\text { - 4-year technical high school. }\end{array}$ \\
\hline May 2024 & $\begin{array}{l}\text { To administer national testing in: } \\
\text { - 5-year technical high school. } \\
\text { - 4-year academic high school. } \\
\text { - 2-year second-degree vocational technical school. }\end{array}$ \\
\hline
\end{tabular}

Source: Authors' compilation.

Elementary school education will be eight years and will be divided into two educational stages:

- Stage I

The first educational phase, comprising Grades I to III of elementary school, are being taught in an integrated format.

\section{- Stage II}

The second educational phase, comprising Grades IV to VIII of elementary school, are being taught as individual subjects. In Stage II, students are required to take the following mandatory subjects: Polish Language, Foreign Language, Second Foreign Language, Music, Art, History, Social Sciences, Environmental Studies, Geography, Biology, Chemistry, Physics, Mathematics, Information Science Technology (IST), Technology, Physical Education and Safety Education. 
- Stage III (secondary education) contains the following:

1. 4-year academic high school,

2. 5-year technical high school,

3. 3-year first-degree vocational technical school,

4. 2-year second-degree vocational technical school.

Students graduating from first-degree vocational technical school (three years) can either enter the job market or continue their education in second-degree vocational technical school (two years). Graduates from the following:

- Academic High School.

- Technical High School .

- Second-degree Vocational School

receive a high school diploma and can enter post-secondary education. The condition for receiving a high school diploma is passing a standardised national test from three mandatory subjects, which are Polish Language, Mathematics and Foreign Language. Student must also pass an exam from one additional subject selected by the student.

Graduates from a Technical High School and Second-degree Vocational School also receive a vocational certificate. Students graduating from a 3-year first-degree vocational technical school receive a vocational certificate and do not have a high school equivalency diploma. These students can not apply for admission into post-secondary institutions.

\section{Job Training: Post-secondary Schools}

Post-secondary schools can prepare graduates for advanced technology careers. Post-secondary schools in Poland are equivalent to community colleges in the United States. Admission to post-secondary schools in Poland is based on earning a high school diploma. The duration of the programme varies from 1 to 2.5 years depending on the programme.

\section{Educational System in Hazleton, Pennsylvania}

The Hazleton Area School District (Hazleton, Pennsylvania) follows the guidelines of the Pennsylvania Department of Education.

The Commonwealth of Pennsylvania K-12 education system serves more than 1.7 million students. Pennsylvania's 500 school districts range in size from approximately 200 students to more than 140,000 students.

The educational system in Pennsylvania follows the guidelines of the Pennsylvania (PA) Department of Education (DoE), as well as the United States (USA) Department of Education (ED). The school system is as follows: 
- Primary (Kindergarten to Grade 2).

- Elementary (Grade 3 to Grade 5).

- Middle School (Grade 6 to Grade 8).

- Academic High School (Grade 9 to Grade 12).

- Career and Technology Centres/Vocational High School (Grade 9 to Grade 12).

- Post-secondary Community Colleges.

The teaching methodology in Kindergarten to Grade 3 uses an integrated approach. The teaching methodology for Grade 4 to Grade 12 uses a subject approach.

Children can start Grade 1 at the age of six. All children are required to attend school until they are eighteen years of age. This is the age that students normally graduate from either an academic or vocational high school. (At the request of their parents, students can stop their formal education at sixteen years of age.) A high school diploma is required to enter postsecondary education.

Students who for some reason did not finish their high school education can take a high school equivalency test and receive a high school equivalency diploma (GED). Students graduating from a vocational high school (Career and Technology Centre) also receive a high school diploma and a trade certificate based on the trade that they have selected. The public education system (Kindergarten to Grade 12) is free of charge.

In addition to the public education system, there are private schools or schools sponsored and managed by religious groups. These schools are obligated to use the required educational standards, as well as to administer standardised testing. Schools operated by religious organisations may have additional subjects containing religious studies (the study of religion is not included in the curriculum of public schools).

Recently, cyber-schools have been created in the United States. Classes are being taught by using interactive Internet programmes. Periodically, these students need to take mandatory tests to guarantee that they are achieving basic performance levels according to state standards. This is a very valuable solution for students living in secluded areas, which would require traveling long distances to school.

There are dual enrolment opportunities for students in Grades 11 and 12. Students can start taking some selected freshman level college courses while in high school. These courses are offered either at the high school during the school hours or at the university during evening hours. The high school normally pays a discounted rate for college courses. The students are considered high school and college (dual enrolment) students at the same time. Dual enrolment allows the students to experience college courses being taught by a university professor while the students are still in high school. 


\section{Job Training: Post-secondary Schools}

Post-secondary programmes focusing on high-tech job training or retraining unemployed or displaced workers are being offered at community colleges. The duration of these programmes is normally two years and graduates receive an associate degree in the selected major.

\section{Educational Standards in Poland}

Structural reform in the Polish educational system was accompanied by a new exam system, with a diagnostic exam at the end of primary school, an exam that determines eligibility for upper secondary options (academic, technical and vocational), at the end of lower secondary, and the national competency exam, at the end of upper secondary.

A new core curriculum was introduced for primary and lower secondary school, and the academic requirements of technical and vocational upper secondary schools were strengthened. Unlike the previous curriculum style, the new curriculum provided frameworks that allowed schools and teachers the flexibility to adapt the curriculum for their own students so that it is aligned with the national frameworks.

The mandatory subjects required by the Polish educational standards are as follows:

- Polish Language.

- Foreign Language and Second Foreign Language.

- Philosophy or Art or Music.

- History.

- Social Sciences.

- Entrepreneurship.

- Geography.

- Biology.

- Chemistry.

- Physics.

- Mathematics.

- Information Science Technology.

- Physical Education.

- Safety Education.

- Etiquette.

Based on scheduled mandatory testing, school districts assess the level of meeting the educational standards. The most common subjects being tested are Mathematics, Reading and Science. 
Test scores in Mathematics, Reading and Science from the Programme for International Student Assessment (PISA) compiled by the Organisation of Economic Co-operation and Development (OECD) are shown in Table 2.

Table 2.

PISA average test scores in Mathematics, Reading and Science

\begin{tabular}{|l|l|}
\hline Subject Tested & Mean Score (2015) \\
\hline Mathematics & 504.5 \\
\hline Reading & 506 \\
\hline Science & 502 \\
\hline
\end{tabular}

Source: data.oecd.org/pisa. DOA: 10.07.2019 (Author compilation).

More details need to be provided as to the specific standards which are evaluated in the Programme for International Student Assessment (PISA) in any given year. The authors will develop a standardised method for the comparison of assessment data in future research.

\section{Pennsylvania Educational Standards}

The Division of Instructional Quality provides guidance, materials and resources to educators regarding curriculum, instruction, assessment and regulations related to the following subjects required by the curriculum:

- Arts and Humanities.

- Driver and Safety Education.

- Economic and Financial Literacy.

- Educating English Learners.

- English Language Arts.

- Environment and Ecology.

- Gifted Education.

- Health and Physical Education.

- Mathematics.

- Science.

- Social Studies.

- Technology Education.

- World Languages.

- English Language Arts. 
The annual Pennsylvania System School Assessment (PSSA) is a standards-based, criterion-referenced assessment which provides students, parents, educators and citizens with an understanding of student and school performance related to the attainment of proficiency of the academic standards. These standards in English Language Arts, Mathematics and Science and Technology identify what a student should know and should be able to do at varying grade levels. School districts possess the freedom to design the curriculum and instruction to ensure that students meet or exceed the standards' expectations.

Every Pennsylvania student in Grades 3 through 8 is assessed in English/Language Arts and Mathematics, unless a student has an Individualized Education Program (IEP) and no standardized testing has been written into it. Every Pennsylvania student in Grades 4 and 8 is assessed in Science. Middle school students enrolled in Algebra 1 may also be given a Keystone Exam in May. The English Language Arts and Mathematics PSSAs include items that are consistent with the Assessment Anchors/Eligible Content aligned to the Pennsylvania Common Core Standards in English/Language Arts and Mathematics.

Individual student scores, provided only to their respective schools, can be used to assist teachers in identifying students who may need additional educational opportunities, and school scores provide information to schools and districts for curriculum and instruction improvement discussions and planning.

Pennsylvania's Core Standards in English Language Arts and Mathematics are relevant to the real world. The Pennsylvania (PA) Core Standards include standards for reading and writing in Social Studies, Science and Technical Subjects designed to help students apply and develop reading and writing skills in all classes. The Common Core Standards were designed because basic math is not enough. The PA Common Core Standards are closely aligned to the adopted National Common Core tests in Math and Language Arts. The results of selected standards assessments are shown in Table 3.

Table 3.

Average test scores in Mathematics, Reading and Science in the USA

\begin{tabular}{|l|l|}
\hline & United States \\
\hline Mathematics & 481 \\
\hline Reading & 499 \\
\hline Science & 498 \\
\hline
\end{tabular}

Source: ncee.org/wp-content/uploads/2014/07/PolandPISA2009-2012.png. DOA: 10.06.2019.

Note: The most current information of national (including Poland) policies related to education can be found in publications from the Education, Audiovisual and Cultural Executive Agency (EACEA) of the European Union (EU) as provided by OCED. 


\section{Comparative Analysis of Educational Standards in Poland and the United States}

A comparative analysis of the results of educational standards testing was done by the National Center on Education and the Economy (NCEE): Center on International Education Benchmarking to learn from the best educational systems. The results are shown in Fig. 1 and Table 4.

The content of the standards and which standards are chosen to be assessed have changed through the years. The methods of assessment, who will be assessed and how students are prepared for assessment needs to be further researched.

Comparing the assessment scores in Poland and the United States, it is obvious that the assessment scores achieved in the Polish educational system are higher. This is true for all three subjects of Mathematics, Reading and Science.

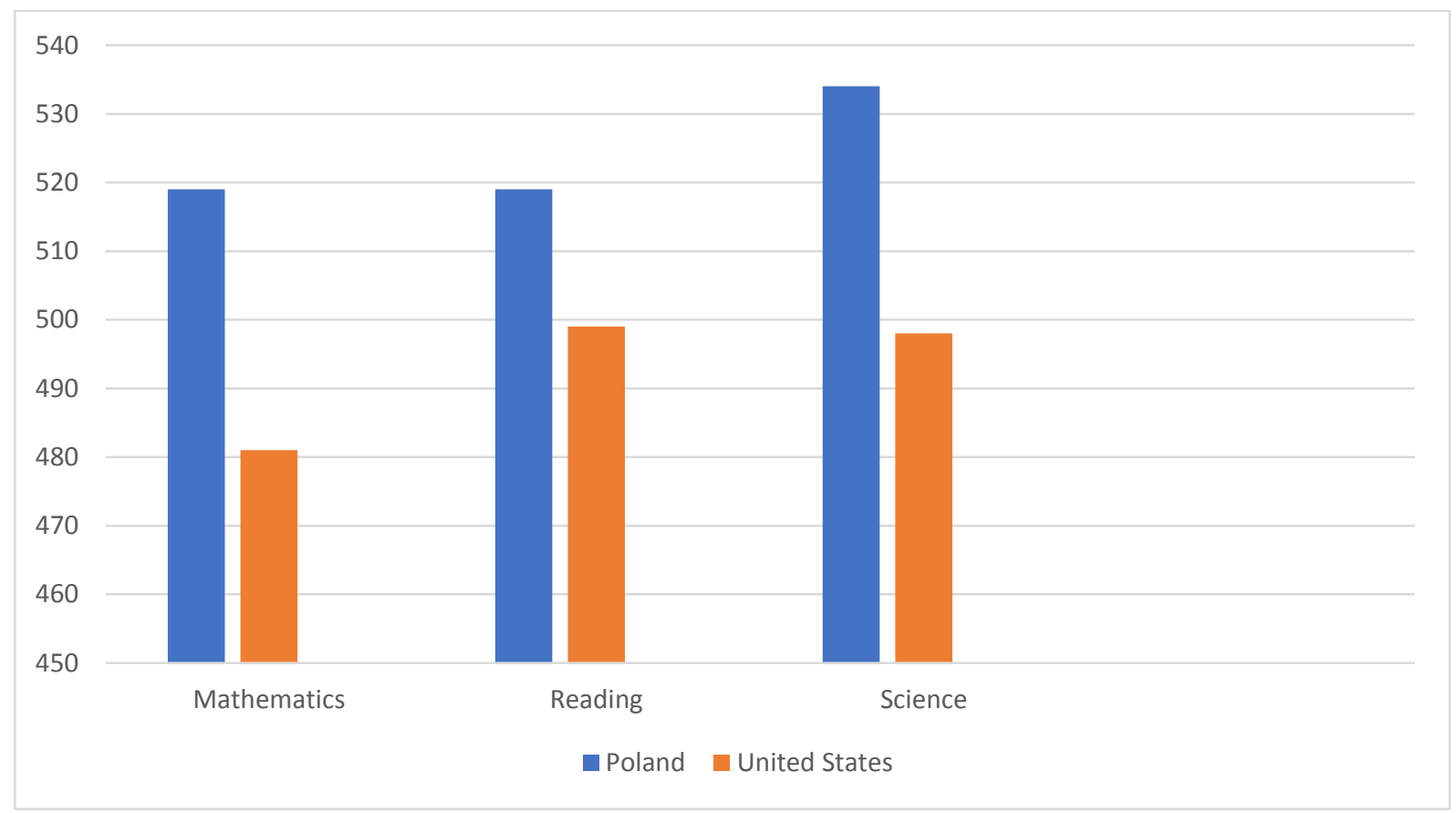

Figure 1. Comparison of assessment scores in Poland and the United States (Author's compilation).

\section{Table 4.}

Comparison of assessment scores in Poland and the United States

\begin{tabular}{|l|l|l|}
\hline & Poland & United States \\
\hline Mathematics & 519 & 481 \\
\hline Reading & 519 & 499 \\
\hline Science & 534 & 498 \\
\hline
\end{tabular}

Note: The most current information of national (including Poland) policies related to education can be found in publications from the Education, Audiovisual and Cultural Executive Agency (EACEA) of the European Union (EU) as provided by OCED.

Source: ncee.org/wp-content/uploads/2014/07/PolandPISA2009-2012.png. DOA: 10.06.2019. 


\section{Funding of the Educational System in Poland}

Education in Poland is funded primarily from public sources. It is estimated that public funds represent around $91 \%$ of funding in school education and around $79 \%$ in higher education. The share of public funding in early childhood education and care is larger and represents around $83 \%$ (OECD, 2018). Comparable data for adult education is not available.

The main sources of public funding for education in Poland include the following:

- general subsidy from the State budget provided to local government units (LGUs);

- State-budget grants for specific purposes (targeted grants) provided to LGUs (for example, for pre-school education, purchase of textbooks and educational resources);

- maintenance grants as part of financial support for learners; care for children aged up to 3 years as part of the Toddler Programme;

- grants for specific purposes and institutions (targeted State-budget grants) and Statebudget subsidies allocated to higher education institutions;

- maintenance and development of the teaching and research capacity;

- financial support for students;

- co-funding for investment projects; tasks related to providing conditions for full participation of disabled people in the educational process;

- LGUs' own resources (for example, from fees and taxes);

- European Union (EU) funds;

- other public funds (for example, the Labour Fund, the National Fund for the Rehabilitation of Disabled People);

- budgets of central government agencies allocated for the training of specific occupational groups.

Grants are also awarded to non-public institutions providing care to children, nursery schools, schools and higher education institutions if they fulfil the requirements laid down in national legislation.

The share of public funding shows areas where the non-public sector plays an important role, but it also reflects varying levels of fees for services offered by public educational institutions.

Families of learners may, however, benefit from various types of support offered as part of the family support system (family allowances and supplementary allowances), the tax system (a so-called family tax benefit), the healthcare system (free healthcare), as well as by schools themselves (e.g. free transport). A child-raising allowance, amounting to 500 zloty/month, has also been granted since 2016. Furthermore, support is available as part of special government programmes: 'School Kit' (Wyprawka szkolna), 'Good Start' (Dobry start) and 'State-funded meals' (Pomoc państwa w zakresie dożywiania). A system of benefits for 
large families (a so-called Large Family Card) has been in place since 2014. Families of disabled pupils are entitled to receive support in various additional forms.

Support is also provided to pupils and students. Pupils in the school system are eligible to receive maintenance- and incentive-type grants as part of the financial support system. Students in all types of higher education institutions may apply for State-budget financial support in various forms, including a maintenance grant, a special grant for disabled persons, a grant for best students awarded by the Rector of a given institution, a grant for outstanding achievements awarded by the Minister and an aid payment. Additionally, students may be granted student loans and credits. In Poland, full-time education at State institutions of higher education is free for Polish citizens. It is also free for foreigners who commence studies at State Higher Education Institutions on the terms applicable to Polish citizens.

Depending on the types of training provided, adult learners may receive financial support, such as a maintenance- or incentive-type grant during a period of learning within the school education system, a grant from the Labour Fund during a period of training as an unemployed person and a training leave if they attend school or participate in further training as employees at the request of their employer.

\section{Funding of the Educational System in Hazleton, Pennsylvania USA}

The Hazleton Area School District (Hazleton, PA USA), aka HASD, receives funding through local, state, federal and private source. Sources of funding for the Hazleton Area School District (HASD) are shown in Table 5.

Table 5.

Hazleton Area School District 2019-2020 general fund revenue sources

\begin{tabular}{|l|l|}
\hline Funding Source & Amount \\
\hline Local (Property Taxes) & $\$ 64,213,767$ \\
\hline State & $\$ 80,363,839$ \\
\hline Federal & $\$ 10,873,193$ \\
\hline Other/Private* & $\$ 215,000$ \\
\hline Total & $\$ 155,665,798$ \\
\hline
\end{tabular}

*Private funding sources include the following.

Source: www.hasd.org. DOA: 10.04.2019.

- Hazleton Area Education Foundation

The purpose of the Hazleton Area Education Foundation is to support and enhance educational and extracurricular activities of the Hazleton Area School District by raising funds and establishing corporate and community partnerships that help offset expenses that are not funded by public authorities. 
- Partners in Education (PIE)

Property taxation is the most important source of revenue-generating taxation at a local level.

Approximately half of the revenue generated from property tax is allocated for education. The exact amount of revenue generated from school district taxes is different from region to region, due to differences in property tax rates that are based not only on the perceived value of the property but on the amount/percentage that a constituency is willing to charge its homeowners as tax.

In some instances, wealthier school districts have reacted to the redistribution of educational funding by actively setting out to ensure that their schools are not endangered or placed on fiscal par with less economically fortunate areas. The Parent Teacher Association (PTA), which can receive state and national funds, and Parent Teacher Organizations (PTOs), which cannot, work with local businesses to ensure that funds other than those generated and allocated by the state are available to their schools.

Parent groups conduct fundraisers and seek monies from private foundations. Some parent groups have sought legal support to ensure adequate funding for their schools. These advocates want to ensure that all schools have a base minimum amount of money on which to operate their programmes and services.

The allocation of funds for education is determined by the Pennsylvania governor. The authorities must determine how the available funds will be divided among all educational entities in the state. States typically funnel education funds to school districts through state departments of education. Schools may receive funds based on the following:

- enrolment,

- educational programmes, or

- types of activities they offer students.

Furthermore, some funds are designated for specific purposes: some can only be used for technology; others are solely for textbooks or school supplies. Some schools may have a pool of money allocated to one resource, while the funds may be needed by another. For example, you may need art supplies for your Grade 3 class, but because no money is specifically allocated for this purchase, districts may have to be creative in how they provide for specific programmes.

Districts may have to consider approaching local businesses for donations of money or supplies. They may also have to apply for a grant from corporations, such as Pennsylvania Power Light (PPL), and foundations, e.g. members of the Association of Pennsylvania Education Foundation (APEF). 


\section{Comparative Analysis of Educational System Funding in Poland and the United States}

The authors have used the latest available data and resources to compile a comparison of the educational funding sources in Poland and the United States. The funding sources and the governing educational bodies are shown in Table 6 .

Since funding for education changes every year according to budget approvals and other funding options, research on the comparison of local, state and federal/national funds will need to be researched in further detail. The funding criteria will need to be standardised and evaluated using similar criteria for specific years.

Table 6.

Comparison of the funding sources

\begin{tabular}{|l|c|c|}
\hline & $\begin{array}{l}\text { Hazleton Area School } \\
\text { District } \\
\text { Hazleton, PA } \\
\text { USA }\end{array}$ & $\begin{array}{l}\text { Śląsk Region, } \\
\text { Rybnik, Poland/ } \\
\text { Ministry of Education }\end{array}$ \\
\hline Funding Sources & $\mathrm{X}$ & \\
\hline $\begin{array}{l}\text { Local Real Estate Taxes } \\
\text { (Mandatory tax paid by property owners.) }\end{array}$ & & $\mathrm{X}$ \\
\hline $\begin{array}{l}\text { Ministry of Education Central Budget - Poland } \\
\text { (Distributed to local municipalities to pay for primary } \\
\text { and secondary education) }\end{array}$ & $\mathrm{X}$ & \\
\hline $\begin{array}{l}\text { Pennsylvania Department of Education/ } \\
\text { United States Department of Education }\end{array}$ & $\mathrm{X}$ & $\mathrm{X}$ \\
\hline Community Foundations/Private Foundations (Grants) & & \multicolumn{1}{|c|}{} \\
\hline
\end{tabular}

\section{Conclusion}

This paper has researched the latest information related to education in Poland and the United States. The subtopics (educational systems from a historical perspective, educational standards and educational funding) were researched for the two countries. The sources of this information include, but were not limited to, the Polish Ministry of Education, Hazleton Area School District, Pennsylvania Department of Education and the United States Department of Education. The educational systems in Poland and the United States have more similarities than differences. The subjects being taught, as well as the educational standards of both countries, are very similar. The educational system in Poland is more uniform throughout the country, because it is centrally administered by the Ministry of Education. The performance scores of students are slightly higher in Poland. This is true in Mathematics, Reading and Science. The educational system in the United States is neither uniform throughout the country nor 
throughout the state of Pennsylvania and may vary from one school district to another school district.

The educational system in the United States allows for dual enrolment (high school and university at the same time). Cyber-school and distance education seem to be more popular and developed in the United States. The authors also feel that streamlining the educational systems and identifying funding sources which provide the most effective results will also help in developing a best practices model.

\section{References}

1. Grebski, M., and Wolniak, R. (2018). Are We Preparing Children for the Future Challenges of the Knowledge-based Economy? Journal of Human Dignity and Wellbeing: Creativity and Innovativeness in Human Education, No. 2(6). Scriptum Publishing Company (University College of Social Sciences and Foreign Languages, Silesian University of Technology, Gliwice, Poland), pp. 51-61. https://johdaw.com/download/journals/ johdaw_2_2018.pdf, 04.29.2019.

2. Grebski, W., and Grebski, M. (2016). Mathematics Preparation in the World: Similarities and Differences. XIV LACCEI (Latin American and Caribbean Consortium of Engineering Institutions) International Multi-Conference for Engineering, Education and Technology. San Jose, Costa Rica, July 20-22, 2016.

3. Wolniak, R., and Grebski, M. (2018). Promoting Creativity and Innovativeness in Education. New York: CreateSpace, ISBN: 9781721903054. 